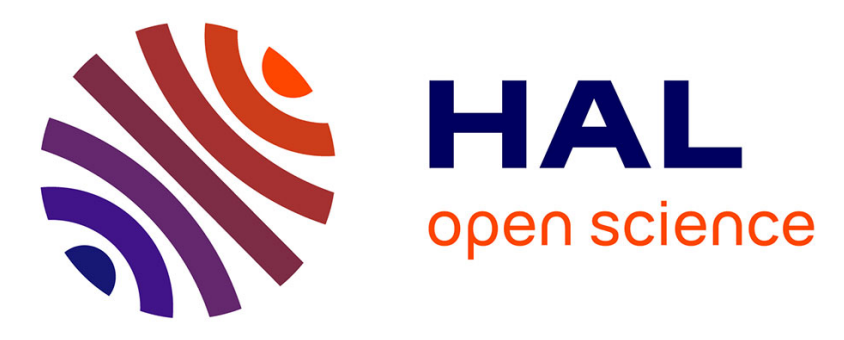

\title{
An innovative coupling between column leaching and oxygen consumption tests to assess behavior of contaminated marine dredged sediments
}

Julien Couvidat, Mostafa Benzaazoua, Vincent Chatain, Fan Zhang, Hassan Bouzahzah

\section{To cite this version:}

Julien Couvidat, Mostafa Benzaazoua, Vincent Chatain, Fan Zhang, Hassan Bouzahzah. An innovative coupling between column leaching and oxygen consumption tests to assess behavior of contaminated marine dredged sediments. Environmental Science and Pollution Research, 2015, 22 (14), pp.10943-10955. 10.1007/s11356-015-4323-z . hal-01308094

\section{HAL Id: hal-01308094 https://hal.science/hal-01308094}

Submitted on 27 Apr 2016

HAL is a multi-disciplinary open access archive for the deposit and dissemination of scientific research documents, whether they are published or not. The documents may come from teaching and research institutions in France or abroad, or from public or private research centers.
L'archive ouverte pluridisciplinaire HAL, est destinée au dépôt et à la diffusion de documents scientifiques de niveau recherche, publiés ou non, émanant des établissements d'enseignement et de recherche français ou étrangers, des laboratoires publics ou privés. 


\title{
An innovative coupling between column leaching and oxygen-consumption tests to assess behavior of contaminated marine dredged sediments
}

\author{
Julien Couvidat ${ }^{1}$, Mostafa Benzaazoua ${ }^{1,2}$, Vincent Chatain ${ }^{1, *}$, Fan Zhang $^{1}$, Hassan Bouzahzah ${ }^{2}$ \\ ${ }^{1}$ Université de Lyon, INSA-Lyon, Laboratoire de Génie Civil et d'Ingénierie \\ Environnementale LGCIE, 20 avenue Albert Einstein, F-69621 Villeurbanne, France \\ ${ }^{2}$ IRME, UQAT, 445 Boul. de l'Université, Rouyn-Noranda, J9X $5 E 4$ Canada \\ *Phone: +33 (0)4 72438190 - Fax: +33 (0)4 72438717 - E-mail: Vincent.Chatain@insa-lyon.fr
}

\begin{abstract}
Purpose: Contaminated dredged sediments are often considered hazardous wastes, so they have to be adequately managed to avoid leaching of pollutants. The mobility of inorganic contaminants is a major concern. Metal sulfides (mainly framboïdal pyrite, copper and zinc-sulfides) have been investigated in this study as an important reactive metal-bearing phase sensitive to atmospheric oxygen action.

Methods: An Oxygen Consumption-Test (OC-Test) has been adapted to assess the reactivity of dredged sediments when exposed to atmospheric oxygen. An experimental column set-up has been developed allowing the coupling between leaching and oxygen consumption test to investigate the reactivity of the sediment.

Results: This reactivity, which consisted of sulfides oxidation, was found to occur for saturation degree between 60 and $90 \%$ and until the 20th testing week, through significant sulfates releases. These latter were assumed to come from sulfides oxidation in the first step of the test, then probably from gypsum dissolution. Confrontation results of OC-Test and leachates quality shows that $\mathrm{Cu}$ was well correlated to sulfates releases, which in turn leads to $\mathrm{Ca}$ and $\mathrm{Mg}$ dissolution (buffer-effect). $\mathrm{Cu}$, and mostly $\mathrm{Zn}$, was associated to organic matter, phyllosilicates and other minerals through organo-clays complexes.

Conclusions: This research confirmed that OC-Test originally developed for mine tailings could be a useful tool in the dredged sediment field which can allow for intrinsic characterization of reactivity of a material suspected to readily reacting with oxygen and for better understanding of geochemical processes that affect pollutants behavior, conversion, and transfer in the environment.
\end{abstract}

Keywords: dredged marine sediment, oxygen consumption test, sulfides, trace metals, leaching, oxidation, organic matter 


\section{Introduction}

Management of contaminated dredged sediment is a requirement of harbors administrators and authorities, which are in charge of the dredging operations. Up to 18.6 million ton of sediment (in dry matter) have been dredged in France (metropolitan and overseas) in 2010, 33.56 million tons in 2009, and 23.2 million tons in 2008 (Le Guyader 2011; Le Guyader 2013). Once extracted from their original environment, sediments are considered as waste materials that have to be adequately managed accordingly to existing regulations (European Council 2002; French Official Journal 2007). Marine sediments are composed mainly of minerals (quartz, various silicates, carbonates, iron and manganese oxy-hydroxides, and sulfides) as well as organic matter (OM). Contaminants are mainly sourced from urban contamination, industrial activities as well as nautical activities. Inorganic pollutants $(\mathrm{Cu}, \mathrm{Zn}, \mathrm{Pb}, \mathrm{Cr}, \mathrm{Hg}, \mathrm{As} . .$.$) are particularly of concern due to their ubiquitous presence and$ their accumulation within sediments. Organometallics, mainly as tin compounds, and organic pollutants are also of significant concern. All those compounds are likely to be harmful towards the environment as well as human health even at low levels, and frequently encountered at various levels in marine sediments (Caplat et al. 2005; Casado-Martínez et al. 2009; Chatain et al. 2013a; Díez et al. 2002; Eek et al. 2008; Jones and Turki 1997; Lions et al. 2010; Mamindy-Pajany et al. 2012; Ribecco et al. 2011; Staniszewska et al. 2011). Sulfides minerals are likely to control the mobility of trace metals in anoxic layers as $\mathrm{Cu}$ or $\mathrm{Zn}$ (Morse and Luther Iii 1999; Salomons et al. 1987; Ye et al. 2011). Metal mobility depends on several processes, as discrete sulfide phases precipitation, complexation with bisulfides, polysulfides or OM, adsorption or coprecipitation within iron sulfides (HuertaDiaz et al. 1998). Their immobilization into metallic sulfides in anoxic environment is not only controlled by thermodynamic parameters, but also depends on ligand exchange reaction kinetic and redox reaction pathways. For instance, $\mathrm{Pb}, \mathrm{Zn}$, and $\mathrm{Cd}$ form $\mathrm{MeS}$ (or MeS2) phases, whereas $\mathrm{Co}$ or $\mathrm{Ni}$ are rather incorporated into pyrite (Morse and Luther Iii 1999). Furthermore, it was stated that pyrite (FeS2) and iron monosulfide (FeS) play a central role in the iron and sulfur cycles in marine sediments (Schippers and Jørgensen 2002).

In fact, sulfides are known as reactive minerals very susceptible to the redox potential. Dredging and landstoring induces oxygen diffusion while water desaturation increases. Molecular oxygen is the main oxidant of reduced sulfur species in oxic environment, as shown in the equation (Eq.1) of pyrite oxidation by molecular oxygen and water (Lowson 1982).

$$
2 \mathrm{FeS}_{2}+7 \mathrm{O}_{2}+2 \mathrm{H}_{2} \mathrm{O} \rightarrow 2 \mathrm{Fe}^{2+}+4 \mathrm{SO}_{4}^{2-}+4 \mathrm{H}^{+}
$$

Oxidation of sulfides can occur and lead to inorganic contaminants release, even at neutral $\mathrm{pH}$ (Salomons et al. 1987). In sulfide bearing sediments, the framboïdal pyrite is considered as the most common form of pyrite in anoxic sediments as well as the most reactive (Pierret et al. 2000). Usually in marine sediments, pyrite concentrations are under $1 \mathrm{wt} . \%$ (Lowers et al. 2007; Schenau et al. 2002), and up to $20 \mathrm{wt} . \%$ in some rare cases (Pierret et al. 2000). Sulfides clearly play a central role towards trace metals mobility, and their reactivity is a key parameter towards assessment of the environmental impact of contaminated sediments. Most studies in the literature focused on sediment geochemical behavior through leaching tests, according to current regulations (Caplat et al. 2005; Chatain et al. 2013a; Chatain et al. 2013b; Guevara-Riba et al. 2004; Prokop et al. 2003; 
Sundaray et al. 2011). Knowledge about parameters linked to this sulfide reactivity should be improved, given the challenges for better management of contaminated dredged sediments. Monitoring of parameters such as $\mathrm{pH}$, oxido-reduction potential (ORP), or trace and major metal concentrations have been promoted during leaching test (Cappuyns and Swennen 2008). Moreover, it is worth mentioning that there are other approaches usually used in the characterization of sulfidic materials. For instance, some mining research scientists used during the last two decades an oxygen consumption-test (OC-Test) to assess the acid mine drainage (AMD) potential of sulfides-rich wastes (Demers et al. 2009; Elberling et al. 2003; Elberling and Nicholson 1996; Mbonimpa et al. 2003; Ouellet et al. 2006). In this study, the authors propose to adapt the OC-test to dredged sediment characterization in order to better understand the geochemical interactions between sulfides, OM and oxygen.

In this context, the main objective of the study is to assess the reactivity and geochemical behavior of dredged sediment by the use of an innovative experimental column set-up allowing the coupling between leaching test and OC-Test. The authors propose to link the oxygen consumption (OC) due to sulfides and OM oxidation to the quality of the leachates (trace metals, sulfates ...) released during a column leaching test on a contaminated harbor sediment.

\section{Material and methods}

\subsection{Sampling, treatment, and preparation of sediment}

The sediment used was dredged in a harbor located in the south of France. It was sampled with a mechanical shovel and sieved at $20 \mathrm{~mm}$. This marine sediment was stored for 5 years to undergo a natural weathering after a short aeration pretreatment. Prior to characterization, the sediment was homogenized by quartering and stored at $4^{\circ} \mathrm{C}$ in darkness.

\subsection{Analytical methods}

\subsubsection{Sediment characterization}

The sediment was characterized for particle size distribution (PSD), total sulfur and carbon, specific gravity (Gs), chemical composition, non-organic sulfur speciation and total organic carbon (TOC). PSD was determined by laser diffraction (Malvern Mastersizer 2000G) after sieving of the sediment at $1 \mathrm{~mm}$. During the PSD analysis, the ultrasounds were applied for $1 \mathrm{~min}$ to allow aggregates breakdown. Total sulfur and total carbon were determined by induction furnace analyser (ELTRA CS-2000). Gs of each sample was measured with an helium gas pycnometer (Micromeritics Accupyc 1330). Chemical composition was determined by inductively coupled plasma atomic emission spectroscopy (ICP-AES, Perkin Elmer Optima $3100 \mathrm{RL}$ ) after a $\mathrm{HNO}_{3} / \mathrm{Br}_{2} / \mathrm{HF} / \mathrm{HCl}$ digestion. Determination of non-organic sulfur speciation was realized by $\mathrm{HCl}$ extraction according to a Sobek method (Sobek et al. 1978). Only HCl-extractable sulfur are determined, mostly sulfates and amorphous sulfides, giving by difference with total sulfur the amount of sulfur under crystallized sulfides forms and non-extractable 
organic sulfur. Content in OM was determined by TOC through sample combustion within a furnace heated to $680^{\circ} \mathrm{C}$. The released gas was then analyzed with non-dispersive infrared gas apparatus.

The mineralogy of samples was determined by X-ray diffraction (XRD) (Bruker AXS D8 advance) equipped with a copper anticathode, scanning over a diffraction angle $(2 \theta)$ range from $5^{\circ}$ to $70^{\circ}$. Scan settings were $0.02^{\circ}$ $2 \theta$ step size and $4 \mathrm{~s}$ counting time per step. The DiffracPlus EVA software (v.9.0 rel.2003) was used to identify mineral species and the TOPAS software (v 2.1) implementing Rietveld refinement was used to quantify the abundance of all identified mineral species (Young 1993). The absolute precision of this quantification method is of the order of $\pm 0.5-1 \%$ (Bouzahzah et al. 2008; Raudsepp and Pani 2003). The samples mineralogy identification was completed by optical microscopy observations. Polished sections prepared with bulk samples (sediment impregnated within an epoxy resin) were observed by reflected light microscopy (Zeiss Axio Imager.M2m). The chemical composition of the individual minerals (stoichiometry) was determined using a scanning electron microscope (Hitachi S-3500N) equipped with an Energy Dispersive Spectrometer (EDS, Silicon Drift Detector X-Max $20 \mathrm{~mm}^{2}$, Oxford) operated under the INCA software (450 Energy). The operating conditions were $20 \mathrm{keV}, \sim 100 \mu \mathrm{A}$ and $15 \mathrm{~mm}$ working distance.

\subsubsection{Leachates analysis}

Leachates were immediately prepared after their recovery from column test for chemical analysis. All recovered leachates were limpid and were filtrated through Minisart $0.45 \mu \mathrm{m}$ syringe filters. To improve the interpretation of geochemical results and investigate the release patterns or involved reactions into the leaching of trace metals, parameters such as $\mathrm{pH}$, ORP and conductivity, some anions $\left(\mathrm{Cl}^{-}\right.$and $\left.\mathrm{SO}_{4}{ }^{2-}\right)$, major elements $(\mathrm{Ca}, \mathrm{Mg}, \mathrm{Mn}, \ldots)$, and dissolved organic carbon (DOC) are monitored into leachates (Cappuyns and Swennen 2008). Leachates were analyzed for trace elements and major dissolved metals by ICP-AES after acidification with $2 \% \mathrm{HNO}_{3}$. Sulfates and chlorides were analyzed using an ionic chromatography (Dionex DX320 HPIC®). DOC concentration was determined by a total organic carbon analyzer (Shimadzu TOC 5000A®). pH, ORP and conductivity measurements were done immediately after each column rinsing and leachates recovery. $\mathrm{pH}$ and conductivity were measured with an Epoxy $\mathrm{pH} \mathrm{Ag/AgCl}$ electrode (Fisherbrand 90437BNC) and an epoxy conductivity electrode (Consort SK10T) on a pH/mV meter (Consort C3020), and ORP was measured using a Radiometer Analytical ${ }^{\circledR}$ combined platinum electrode [Pt/Ag/AgCl, $+197 \mathrm{mV}$ vs. Normal Hydrogen Electrode (NHE)].

\subsection{Leaching column and Oxygen Consumption-Test}

Highly reactive minerals when exposed to oxidizing environment may lead to pollution by releasing acidity and metals. In this context, a column leaching test was used to assess the leachability of the studied sediment. The cell column is made with transparent Plexiglas ${ }^{\circledR}$ of approximately $10.1 \mathrm{~cm}$ diameter and $25.4 \mathrm{~cm}$ height (Fig. 1). Several openings are located around the chamber allowing probes and fluid inlet and outlet. The top of the device is a removable cap with a large opening for the oxygen sensor. A plastic plate pierced with low diameter holes $(2 \mathrm{~mm})$ is set in the lower third of the chamber, to fill with the sample. Geotextile film is inserted between the sample and the plate. A drain is available in the bottom of the chamber for flushing the device. Sediment was 
placed into the chamber in a manner to have same porosity $(n=0.6)$ as its state when deposited in the field (Capilla et al. 2006). Testing consisted of 15 leaching cycles. The cell flushing was conducted each 14 days by addition $500 \mathrm{~mL}$ of deionized water at the top of the column. Leaching behavior of the sediment was investigated in parallel with the OC-Test as shown in Fig. 1. An oxygen sensor (Teledyne Analytical Instruments R-17A) is inserted at the top of the sealed column. The sensor measurement principle is based on an electrochemical galvanic battery, using the half-cell $\mathrm{Pb} / \mathrm{PbOOH}$ to reduce oxygen. Consumption of oxygen by the sensor itself is therefore considered as negligible. The induced current of the reaction is directly proportional to the partial pressure of oxygen in the gas phase; the sensor generates an output signal in form of voltage every 5 seconds. Accuracy of the sensor is $0.1 \%$ in oxygen concentration. A data-logger (OMEGA Engineering OM-CPQUADVOLT-100MV) is connected to the sensor and converts the output signal which is recorded by software on a computer.

\subsubsection{Oxygen flux assessment}

Oxygen Consumption test is a method that allows linking the products of the oxidation reaction analyzed within the leachates (i.e., sulfates and trace metals), with the main oxidant which is the oxygen (Lowson 1982). This approach was developed for mine tailings to assess their reactivity by measuring the consumption rate of airoxygen (Elberling and Nicholson 1996; Elberling et al. 1994; Mbonimpa et al. 2012).

Essentially, the method consists in measuring the oxygen concentration decreases in an air filled chamber located above the column during a short time period. The decrease in $\mathrm{O}_{2}$ concentration can be converted into an oxygen flux by using Fick's Laws. This method was initially designed for determining reaction rates of sulfide tailings. The consumption of oxygen in the chamber can be related to the reactivity of sulfides through oxidation with molecular oxygen. The relation between oxygen flux through the sediment and the decrease in oxygen concentration in the sealed chamber is based on fundamental gas diffusion laws (in this study, only Fickian gas transport mechanisms are considered). Solving Fick's second law expressed with a first-order kinetic reaction term for steady state flux and specified boundary conditions gives the following equation (Eq. 2) for the flux at the cover surface (Elberling et al. 1994):

$$
F_{L}=C_{0}\left(K_{r} D_{e}\right)^{\frac{1}{2}}
$$

where $K_{r}\left[\mathrm{~T}^{-1}\right]$ is the first-order reaction rate coefficient for the system, $D_{e}\left[\mathrm{LT}^{-2}\right]$ is the effective diffusion coefficient and $C_{0}\left[\mathrm{ML}^{-3}\right.$ or MolL $\left.{ }^{-3}\right]$ is the atmospheric concentration of oxygen. Solving the continuity equation (which reflects the oxygen being consumed in the head space) for the initial condition $C=C_{0}$ at $t=0$, the following solution is obtained (Eq. 3):

$$
\ln \left(C / C_{0}\right)=-t\left(K_{r} D_{e}\right)^{\frac{1}{2}}\left(\frac{A}{V}\right)
$$

where $A\left[\mathrm{~L}^{2}\right]$ and $V\left[\mathrm{~L}^{3}\right]$ are the area and the volume of the source reservoir, respectively. The slope of the plot of $\ln \left(C / C_{0}\right)$ versus time gives the value of $\left(K_{r} D_{e}\right)^{1 / 2}$ when $A / V$ is known. This term is substituted into Eq. (2) to evaluate the flux of oxygen at the surface. The standard OC test requires only a small change in oxygen concentration $\left(2\right.$ to $3 \% \mathrm{O}_{2}$ ) in the headspace over a 1- to 3-hour(s) period so that changes in oxygen 
concentration within the pore spaces are insignificant during the testing period to comply with the interpretation assumption of steady state flux. Details of the interpretation method for the standard OC method are given in (Elberling et al. 1994) and (Mbonimpa et al. 2003).

\subsubsection{Influence of saturation degree on sulfide reactivity}

Sulfides minerals can be oxidized when exposed to water and $\mathrm{O}_{2}$ action (Eq. 1). The degree of saturation $\left(\mathrm{S}_{\mathrm{r}}\right)$ related to water content of samples has an important impact on sulfides reactivity (Bouzahzah et al. 2012; Mbonimpa et al. 2003). In fact, a low $S_{\mathrm{r}}$ (low water content) reduces the water availability reducing the oxidation reaction, while a high $\mathrm{S}_{\mathrm{r}}$ reduces the oxygen availability due to the low solubility of $\mathrm{O}_{2}$ in water (Ouangrawa et al. 2009).

A preliminary test was performed to study the sensitivity of the OC-Test to the $S_{r}$ of sediments, and to provide the optimal duration of cycles (Fig. 2). The optimal $S_{\mathrm{r}}$ is comprised between 70 and $90 \%$, with a maximum at $80 \%$. Moreover, the $\mathrm{S}_{\mathrm{r}}$ decrease from 90 to $70 \%$ took 2 weeks. According to those results, OC-Tests were carried out every 14 days, 12 days after the previous flush.

\section{Results}

\subsection{Sediment characterization}

The physical and chemical properties of the studied sediment are presented in Table 1. The measured Gs is 2.55 $\mathrm{g} / \mathrm{cm}^{3}$, close to Gs of quartz and carbonate minerals which are usually the predominant constituents of sediments. PSD shows that the sediment can be classified as a fine silty sediment, with $50 \%$ of the particles under $20 \mu \mathrm{m}$ $\left(\mathrm{D}_{50}=19.24 \mu \mathrm{m}\right)$. Organic matter is an important constituent of the sediment. Indeed, TOC is about $6.3 \%$, in the range of usual values for marine sediments (Tessier et al. 2011). The total sulfur content is about $2 \mathrm{wt} . \%$, where $51 \%$ extractable with $\mathrm{HCl}$ would represent mostly sulfates minerals as gypsum (except barite), and potential reactive sulfides, the remaining $49 \%$ would represent mostly well-crystallized sulfides as pyrite, and the unassessed pool of organic sulfur.

Trace metals are investigated in the whole sediment (Table 2). Some trace metals, as $\mathrm{Cu}, \mathrm{Pb}$ or $\mathrm{Zn}$, are monitored in dredged sediments according to French regulation (French Official Journal 2007), relative to threshold levels to be taken into account for the analysis of a marine sediment sea rejection. Two threshold levels N1 and N2 are determined through this regulation. If the assessed sediment has one trace metal over the $\mathrm{N} 2$ level, it is treated as "contaminated sediment", which means it cannot be rejected into the sea but needs to be managed and/or treated in a proper way. Iron $(\mathrm{Fe})$ is related to some of the most important metal key phases in marine sediments, e.g. oxy-hydroxides and sulfides. The Fe is not concerned by regulation, and is usually found in the same extent that it is found in this marine sediment. $\mathrm{Cu}, \mathrm{Pb}$ and $\mathrm{Zn}$ which are concerned by French regulation were measured in leachates. They are found in the sediment at very high levels, above ten times higher than N2 threshold level for copper, five times for the two others.

The sample mineralogy was determined by X-Ray diffraction (Table 3) and shows that $34.6 \mathrm{wt} . \%$ of minerals are silicates (19.3 wt.\% of clays and 15.3 wt.\% of quartz). The carbonate minerals represent $52.5 \mathrm{wt} . \%$ of the 
sample, with $13.6 \mathrm{wt} . \%$ of dolomite and 38.9 wt. \% of calcite. Pyrite is the only crystallized form of sulfide significantly found in the sediment, which accounts for $2 \mathrm{wt} . \%$ of the quantified minerals. In addition, $5 \mathrm{wt} . \%$ of gypsum is determined as well as about $1.1 \mathrm{wt} . \%$ of iron oxide (magnetite). Halite ( $0.8 \mathrm{wt} . \%)$ is also identified by $\mathrm{XRD}$ as some frequent minerals in marine sediment.

Optical and scanning electron microscopic (SEM-EDS) observations show well-preserved pyrite and some framboïdal ones in particular (Fig. 3a). A ferrous oxide layer is covering surface of massive pyrites, suspected to act as a protective layer (passivation) (Fig. 3b). Iron oxide layer seems to be Goethite, or Lepidocrocite, according to $\mathrm{Fe} / \mathrm{O}$ ratio. Both massive and framboïdal pyrite are surrounded by clays and OM aggregate, containing calcite, quartz, and traces of copper and zinc. Sulfides might have been preserved from oxidation either by the protective passivation layer of iron oxy-hydroxides, and the organo-clays aggregate (Lions et al. 2010).

\subsection{Column leaching test}

\subsubsection{Conductivity, $\mathrm{pH}$ and Eh parameters of leachates}

The column leaching test was conducted over 30 weeks, with a flush every 2 weeks. Chemical parameters of recovered leachates are presented in Fig. 4. Initial conductivity was high at about $6.4 \mathrm{mS} / \mathrm{cm}$, and decreased to $1.1 \mathrm{mS} / \mathrm{cm}$ after 16 weeks (Fig. 4a). In the early stage, the fast release of soluble products occurred, and then decreased strongly. The same behavior was observed for chlorides, which concentration decreased from 400 to $10 \mathrm{mg} / \mathrm{kg}$ (halite dissolution). During the column leaching test, leachates presented stable $\mathrm{pH}$ values around 7.5 (Fig. 4b). ORP oscillated around $+500 \mathrm{mV} / \mathrm{SHE}$ for the 7 first cycles and then reached a second state around $+370 \mathrm{mV} / \mathrm{SHE}$ until the end of the test.

\subsubsection{Chemistry of leachates}

Sulfates content in the leachates are presented in Fig. 5a. Sulfur total depletion during the 30 testing weeks was of $16 \%$. Sulfates in leachates were highly concentrated especially at the beginning of the test $(1200 \mathrm{mg} / \mathrm{kg} \mathrm{DM})$. Concentrations decreased to reach a plateau around $400 \mathrm{mg} / \mathrm{kg}$ DM between the $16^{\text {th }}$ and $20^{\text {th }}$ weeks. This leachable sulfur fraction would be linked either the oxidation of accessible framboïdal pyrites, or the dissolution of soluble sulfates mineral phases. $\mathrm{Ca}$ and $\mathrm{Mg}$ are significantly released during the first weeks of the leaching test (Fig. 5b). Their respective concentrations were 250 and $150 \mathrm{mg} / \mathrm{kg} \mathrm{DM}$ at the beginning of the test, and decreased throughout weeks to reach a stable value around 130 and $25 \mathrm{mg} / \mathrm{kg}$ DM respectively. Accordingly to the sediment mineralogy, $\mathrm{Mg}$ and $\mathrm{Ca}$ are expressed mainly as dolomite and calcite. $\mathrm{Ca}$ is also associated to gypsum whose dissolution would cause the release of $\mathrm{Ca}$ into recovered leachates. Dolomite and calcite are responsible for buffering effect. As previously observed, it can be expected that leaching of those minerals reflects the acid $\left(\mathrm{H}^{+}\right)$neutralization following metallic sulfides oxidation. Carbone was also investigated on its dissolved forms into leachates. DOC has roughly the same behavior as chlorides which rapidly decreased after the first testing cycles at $49 \mathrm{mg} / \mathrm{kg}$ DM to $8 \mathrm{mg} / \mathrm{kg} \mathrm{DM}$ at $5^{\text {th }}$ cycle and then reached a plateau around $5 \mathrm{mg} / \mathrm{kg}$ DM. 
$\mathrm{Cu}, \mathrm{Fe}$ and $\mathrm{Zn}$ concentrations into leachates are presented in Fig. 6. Pb was under the detection limit of ICP-AES on all analyzed leachates and it is not discussed in this section. Pb's leachability is known to be very low in a range of $\mathrm{pH}$ between 6.5 and 12, and it is much more sensitive to acidic $\mathrm{pH}$ (Chatain et al. 2013b; Trefry and Metz 1984). Contrary to $\mathrm{Pb}$, and as observed in literature (Dold and Fontboté 2002; Warwick et al. 1998), Zn was released during the whole experiment with concentrations between 0.1 and $0.4 \mathrm{mg} / \mathrm{kg}$. Moreover, $\mathrm{Cu}$ decreased progressively from 0.2 to $0.01 \mathrm{mg} / \mathrm{kg} \mathrm{DM}$. Fe was released at very small concentrations indicating a probable precipitation of fresh Fe-oxi-hydroxides. Other trace metals (arsenic, chromium, manganese) were mostly under detection limit.

\subsection{Oxygen consumption test}

Contrary to mine tailings, $\ln \left(\mathrm{C} / \mathrm{C}_{0}\right)$ versus time plot provided a hyperbolic curve instead of a straight line, due to the weaker reactivity of sediments. A punctual reactivity is therefore taken into account to calculate the oxygen flux $\left(F_{L}\right)$, represented by the slope of the curve $\left(\ln \left(C / C_{0}\right)=f(t)\right)$ which is linear between 0 and 2 minutes. $\mathrm{O}_{2}$ consumption was realized over the 30 weeks of the testing (Fig. 7). Important oxidation occurred at the beginning of the test (between the second and the eighth weeks) with more than $100 \mathrm{~mol}\left(\mathrm{O}_{2}\right) \cdot \mathrm{m}^{-2} \cdot \mathrm{s}^{-1}$. This $\mathrm{O}_{2}$ consumption then gradually decreased to reach zero consumption from the $20^{\text {th }}$ week until the end of the test. The measured $\mathrm{S}_{\mathrm{r}}$ during every $\mathrm{O}_{2}$ consumption test varied roughly between 60 and $70 \%$ and no correlation was observed between the decrease of $\mathrm{O}_{2}$ consumption and $\mathrm{S}_{\mathrm{r}}$.

\section{Discussion}

The objective of this study was to assess the reactivity and the geochemical behavior of the sediment by the use of an experimental column set-up, with the coupling between leaching test and OC-Test. Elucidation of this geochemical behavior depends on essential factors, environmental reagents, mineralogy of the sediment and products monitored into leachates, whose interactions are summarized in a schema (Fig.8). This set-up allows looking into main processes at work in the sediment coming from those interactions, which will be discussed afterward.

\subsection{Oxygen consumption behavior}

The fast decrease of oxygen consumption observed during the first cycles of testing let to make some interrogations. Firstly, OM is the major difference between mine tailings and marine sediments. Moreover oxidation of $\mathrm{OM}$ in aged marine sediment is considered to have minor or even no impact on OC, which is indicated by DOC and OC behaviors (Fig. 8). DOC has quickly reached a plateau after two cycles, whereas OCTest has showed important variations until $5^{\text {th }}$ cycle. And despite a possible residual oxidation of OM until the end of the test, no OC is monitored. Most of the reactive OM has been oxidized all along the years of storage. The remaining, regardless of its importance, is deeply linked to the sediment properties through aggregation and has a very slow microbial oxidation rate towards sulfides oxidation (Mtambanengwe et al. 2004; Puget et al. 2000). More generally, it was thought that differences in kinetic of the respective reactions, e.g. sulfides oxidation and organic matter mineralization, lead to observations at different timescale. 
The Column leaching test was designed for 4 to 6 months in order to assess sulfides oxidation. The oxygen consumption progressively decreased after $10^{\text {th }}$ week to reach zero at $20^{\text {th }}$ week until the end of the test. In fact, this reduction in OC-Test may be attributed to a sulfide oxidation inhibition. Aggregation of sulfides with clays, OM and other minerals, as seen by SEM observations (Fig. 3a), can act as a protective layer towards oxygen. Moreover, passivation of sulfides' surface by precipitation of freshly produced Fe-oxy-hydroxides is considered to contribute to the decrease of OC during the testing (as seen in Fig. 3b). After the sample dismantling on column set-up, it was observed that the top layer of the sediment was hardened, reminiscent of the Hardpan phenomenon currently happening to sulfidic mine wastes (Blowes et al. 1991; Graupner et al. 2007). The induced decrease of oxygen consumption and diffusion into the sediment might be furthered by the diminution of the oxidant activity (ORP), as observed.

\subsection{Oxidation/neutralization processes}

Sulfates are oxidation products of sulfides, and though directly linked to oxygen consumption (Fig. 8). This reaction leads to acidity production (according to Eq. 1) which is mostly neutralized by carbonates (Eq. 4):

$$
\mathrm{CaCO}_{3}+\mathrm{H}^{+} \rightarrow \mathrm{HCO}_{3}^{-}+\mathrm{Ca}^{2+}
$$

Thereby, oxidation is followed by concomitant production of neutralization products, such as $\mathrm{Ca}, \mathrm{Mg}$, and dissolved inorganic carbon (DIC) (Fig. 8). In mine tailings field, the geochemical behavior of a sample is graphically characterized by an oxidation-neutralization curve between neutralization cations (e.g. Ca, Mg, and $\mathrm{Mn}$ ) and sulfates (Benzaazoua et al. 2004). This is particularly used to determine the long term acid-generating potential of hazardous tailings. In our case, by plotting $\mathrm{Ca}+\mathrm{Mg}$ versus released sulfates, a proper alignment with good correlation is obtained (Fig. 9a). Mn is not considered because its concentrations into leachates are under the detection limit of ICP-AES. A good correlation between $\mathrm{Ca}+\mathrm{Mg}$ versus sulfates illustrates the oxidationneutralization effect that occurred in anoxic dredged sediment, as well as in mine tailings. Furthermore, sulfates leaching behavior is roughly similar with those of OC-Test, $\mathrm{Eh}, \mathrm{Ca}$, and $\mathrm{Mg}$ leachates analysis, with a high plateau from the beginning of the test until $10^{\text {th }}$ week (600 to $1300 \mathrm{mg} / \mathrm{kg} \mathrm{DM}$ ), and a lower one after (about $400 \mathrm{mg} / \mathrm{kg} \mathrm{DM}$ ). This change in sulfates leaching behavior could be explained by two different origins of sulfates: oxidation of sulfides first according to sulfides' oxidation equation (Eq. 1) and OC-Test, and dissolution of sulfates mineral phases after.

Dissolution of sulfates compounds might release sulfates ions in leachates and participate to the observed correlation, when OC is over. Thus, according to XRD observations, the release of sulfates and calcium could be attributed to gypsum (Fig. 8). Indeed, Gypsum dissolution is known to be influenced by pH, temperature or competitive ions. Into distilled water, its maximum solubility is $2.85 \mathrm{~g} / \mathrm{L}(16.6 \mathrm{mmol} / \mathrm{L})$ between 30 and $40^{\circ} \mathrm{C}$, reaching $3.8 \mathrm{~g} / \mathrm{L}(22.1 \mathrm{mmol} / \mathrm{L})$ into seawater. Gypsum solubility decreases in presence of common ions $\mathrm{Ca}^{2+}$ and $\mathrm{SO}_{4}{ }^{2-}$ (Tanji 1969; Visconti et al. 2010).

Sulfates released in the first plateau exceed the theoretical concentrations of solubilized gypsum, even in the case of high ionic strength leaching solution without any competitive ions. In fact, after placing the sediment in the column for testing, reactive sulfides are oxidized and concomitant oxidation-neutralization products are released 
into pore water. Dissolution of gypsum in those conditions might be not furthered, but if it occurred, dissolved concentrations released are much lower than those released by the sulfide oxidation. When oxidation decreased, oxidation-neutralization products have lessened. Dissolution of gypsum could have increased, or at least became more important than oxidation products, as other authors are observing same behavior for gypsum for column leaching test with distilled water (Lions et al. 2007). This hypothesis can be seen graphically by calculating molar ratios of calcium versus sulfates, and calcium versus magnesium (Fig.9b). Theoretically, oxidationneutralization reactions produce a Ca versus sulfates ratio of 0.5 , whereas in the case of a congruent dissolution of gypsum it must be 1 . Moreover, according to a major competition between calcite and dolomite towards neutralization, $\mathrm{Ca}$ versus $\mathrm{Mg}$ ratio has to be close to 1 in the first case, and much higher for dissolution of gypsum.

By plotting those ratios versus time, Ca versus sulfates ratio is about 0.5 at the beginning, and close to 0.9 at the end of the testing. Ca versus $\mathrm{Mg}$ ratio is also close to 1 firstly and then reaches 7, which supports the fact that sulfates are mostly released from sulfides oxidation in the first part of the test. With the decrease of oxidation, gypsum (or other sulfates minerals) dissolution might become the major source of sulfates.

pH stabilization around 7.5 and the $\mathrm{Ca}$ and $\mathrm{Mg}$ content into leachates are the main direct observation of the buffer effect. Ca releases are increasingly found into leachates until the $10^{\text {th }}$ week, issued from dissolution of carbonates minerals, calcite and dolomite, as neutralization response to acidity generated by sulfides oxidation. Ca concentrations then decreased to reach a plateau. $\mathrm{Mg}$ decreased gradually to reach a plateau after $14^{\text {th }}$ week. It is in accordance with the lessening of oxygen consumption observed around the $10^{\text {th }}$ week, linked to the decrease of the sulfides oxidation. Dissolved inorganic carbon into leachates is constantly found under $6 \mathrm{mg} / \mathrm{kg} \mathrm{DM}$ throughout the testing. Carbonates precipitation must occur as $\mathrm{pH}$ remains neutral-basic into the sediment.

\subsection{Trace metals behavior}

According to the sediment's mineralogy, Fe appears mainly associated to clays minerals, (chamosite and illite), sulfides (mostly pyrite) and magnetite. Pyrite is the most probable leaching phase for Fe in the column-leaching test conditions, as physicochemical conditions do not particularly enhance reduction of iron oxides phases. Fe is very sensitive to redox potential and $\mathrm{pH}$, and it precipitates under hydroxide form $\left(\mathrm{Fe}(\mathrm{OH})_{3}\right)$ in neutral-oxidant environment, as this form predominates over $\mathrm{pH} 6$ for Eh between 0 and 0.75V (Pourbaix et al. 1963).

Released concentrations of $\mathrm{Cu}$ in leachates are well correlated to oxygen consumption, and decrease constantly to reach a plateau when no oxidation is monitored. $\mathrm{Cu}$ is also found to be well correlated with released sulfates, especially in the first part of the test (Fig. 10a), and likewise DOC at the same time (Fig.10b). In fact, Cu is known to be linked to organic matter and sulfides (Caplat et al. 2005; Förstner et al. 1981). In the second part of the test, sulfates, $\mathrm{Cu}$ and DOC reached a plateau. $\mathrm{Cu}$ probably comes from the organo-clays aggregate observed in SEM picture (Fig. 3a and 3b), which is associated with minerals and organic matter, as well as trace metals as $\mathrm{Cu}$ and $\mathrm{Zn}$.

$\mathrm{Zn}$ concentrations are more important into leachates than $\mathrm{Cu}$ during the whole test. It was reduced by half during the second part of the testing, after $14^{\text {th }}$ week. Zn well correlates with sulfates and DOC (Fig. 10a and b). In case of sulfidic origins of $\mathrm{Zn}$, Fe-oxi-hydroxides phases and phyllosilicates have been found to reduce $\mathrm{Zn}$ mobility after sulfides oxidation (Isaure et al. 2002; Isaure et al. 2005). Moreover, $\mathrm{Zn}^{2+}$ is a stable divalent cation which 
has a strong affinity for OM (Sauvé et al. 2000), as well as carbonates (Chatain et al. 2013b). Those phases could explain $\mathrm{Zn}$ leaching, even at neutral $\mathrm{pH}$. According to SEM pictures and diffuse leaching behavior, $\mathrm{Zn}$ is more probably associated to organo-clays aggregates.

\section{Conclusion}

Sulfides have been investigated in this sediment. Pyrite is found to be the major crystallized sulfides, still present despite aeration pretreatment. High reactivity of sulfides when exposed to atmospheric oxygen in sedimentary matrix was assessed with an experimental system. This reactivity was found to occur for saturation degree between 60 and 90\%. A column leaching test coupled with an Oxygen Consumption-Test was carried out to better understand the behavior of dredged marine sediment when exposed to ambient air (Fig. 8). Oxygen consumption was found to occur firstly for some minutes when pilot is closed to run the test, and oxygen consumption was compared on the basis of the 2 first minutes.

This method showed a variation of oxidation activity which could correlate to the leaching behavior. We found that organic matter should have very little influence on oxygen consumption at such timescale, by monitoring DOC into leachates. $\mathrm{Fe}$ is suspected to mostly precipitate after oxidation of iron sulfides phases, whereas $\mathrm{Cu}$ readily leached from sulfides phases when oxidation occurred, and with dissolved organic matter then. $\mathrm{Zn}$ is associated to organo-clays complexes, which contained other reactive minerals as carbonates, and leached during the whole test. Sulfates are oxidation products of sulfides, and the acidity generated by the oxidation reaction is neutralized by carbonates minerals which released $\mathrm{Ca}$ and $\mathrm{Mg}$ ions as neutralization products into leachates. Sulfates released after the end of oxidation could be dissolution products of sulfates minerals phases, such as gypsum, favored by the decrease of competitive sulfates and calcium ions into pore water.

Despite the weathering of the material, and the oxidizing and natural leaching conditions to which it was subjected, this sediment was able to show a reactive leaching pattern such as oxidation-neutralization phenomenon. Storage and climatic conditions lead to modification of the physicochemical structure of the sediment, surface sealing at oxygen and water, inducing a decrease of Eh and leachability inside the batch. But, we notice that this apparent stabilization can be seen as a metastable state and modifications as sampling, dumping, staggering, may lead to more or less temporary reactive behavior, and subsequent leaching of hazardous substances, as it was stated before (Lions et al. 2007). This OC-Test originally developed for mine tailings was thus found to be a useful tool in the dredged sediment field, prior to assess the reactivity of a material suspected to readily react with oxygen.

\section{Acknowledgment}

The authors are grateful to EEDEMS (French research network on waste and polluted materials management) for experimental support. Author's acknowledgments also go to University of Quebec (UQAT) for their support in the mineralogical and physicochemical analyses. 


\section{Conflicts of interest}

The authors declare that there is no conflict of interests regarding the publication of this paper.

\section{References}

Benzaazoua M, Bussière B, Dagenais AM, Archambault M (2004) Kinetic tests comparison and interpretation for prediction of the Joutel tailings acid generation potential Environmental Geology 46:1086-1101 doi:10.1007/s00254-004-1113-1

Blowes DW, Reardon EJ, Jambor JL, Cherry JA (1991) The formation and potential importance of cemented layers in inactive sulfide mine tailings Geochimica et Cosmochimica Acta 55:965-978 doi:http://dx.doi.org/10.1016/0016-7037(91)90155-X

Bouzahzah H, Benzaazoua M, Bussière B (2012) Modification and automation of the humidity cell test protocol to favor tailings reactivity Proceedings of the 9th ICARD, Ottawa, ON, Canada

Bouzahzah H, Califice A, Benzaazoua M, Mermillod-Blondin R, Pirard E Modal analysis of mineral blends using optical image analysis versus $\mathrm{X}$ ray diffraction. In: Proceedings of International Congress for Applied Mineralogy ICAM08, Brisbane, Australia, 2008. AusIMM,

Capilla X, Schwartz C, Bedell J-P, Sterckeman T, Perrodin Y, Morel J-L (2006) Physicochemical and biological characterisation of different dredged sediment deposit sites in France Environmental Pollution 143:106116 doi:http://dx.doi.org/10.1016/j.envpol.2005.11.007

Caplat C, Texier H, Barillier D, Lelievre C (2005) Heavy metals mobility in harbour contaminated sediments: The case of Port-en-Bessin Marine Pollution Bulletin 50:504-511 doi:10.1016/j.marpolbul.2004.08.004

Cappuyns V, Swennen R (2008) The Use of Leaching Tests to Study the Potential Mobilization of Heavy Metals from Soils and Sediments: A Comparison Water Air Soil Pollut 191:95-111 doi:10.1007/s11270-0079609-4

Casado-Martínez MC, Forja JM, DelValls TA (2009) A multivariate assessment of sediment contamination in dredged materials from Spanish ports Journal of Hazardous Materials 163:1353-1359 doi:http://dx.doi.org/10.1016/j.jhazmat.2008.07.106

Chatain V et al. (2013a) Mineralogical study and leaching behavior of a stabilized harbor sediment with hydraulic binder Environ Sci Pollut Res:1-9 doi:10.1007/s11356-012-1141-4

Chatain V, Blanc D, Borschneck D, Delolme C (2013b) Determining the experimental leachability of copper, lead, and zinc in a harbor sediment and modeling Environ Sci Pollut Res:1-9 doi:10.1007/s11356-0121233-1

Demers I, Bussière B, Mbonimpa M, Benzaazoua M (2009) Oxygen diffusion and consumption in low-sulphide tailings covers Canadian Geotechnical Journal 46:454-469 doi:doi:10.1139/T08-132

Díez S, Ábalos M, Bayona JM (2002) Organotin contamination in sediments from the Western Mediterranean enclosures following 10 years of TBT regulation Water Research 36:905-918 doi:10.1016/s00431354(01)00305-0

Dold B, Fontboté L (2002) A mineralogical and geochemical study of element mobility in sulfide mine tailings of $\mathrm{Fe}$ oxide $\mathrm{Cu}-\mathrm{Au}$ deposits from the Punta del Cobre belt, northern Chile Chemical Geology 189:135163 doi:http://dx.doi.org/10.1016/S0009-2541(02)00044-X

Eek E, Cornelissen G, Kibsgaard A, Breedveld GD (2008) Diffusion of PAH and PCB from contaminated sediments with and without mineral capping; measurement and modelling Chemosphere 71:1629-1638 doi:http://dx.doi.org/10.1016/j.chemosphere.2008.01.051

Elberling B, Balić-Žunić T, Edsberg A (2003) Spatial variations and controls of acid mine drainage generation Environmental Geology 43:806-813 doi:10.1007/s00254-002-0695-8

Elberling B, Nicholson RV (1996) Field determination of sulphide oxidation rates in mine tailings Water Resour Res 32:1773-1784 doi:10.1029/96wr00487

Elberling B, Nicholson RV, Reardon EJ, Tibble R (1994) Evaluation of sulphide oxidation rates: a laboratory study comparing oxygen fluxes and rates of oxidation product release Canadian Geotechnical Journal 31:375-383 doi:doi:10.1139/t94-045

European Council (2002) Commission decision of 3 may 2000 replacing Decision 94/3/EC establishing a list of wastes, consolidated version of 01 january 2002. (in

Förstner U, Calmano W, Conradt K, Jaksch H, Schimkus C, Schoer J (1981) Chemical speciation of heavy metals in solid waste materials (sewage sludge, mining wastes, dredged materials, polluted sediments) 
by sequential extraction. Universitätsbibliothek der Technischen Universität Hamburg-Harburg, Hamburg-Harburg (in

French Official Journal (2007) JORF n ${ }^{\circ} 240$ du 16 octobre 2007 p. 17002 texte $n^{\circ} 1$. (in French)

Graupner T et al. (2007) Formation of sequences of cemented layers and hardpans within sulfide-bearing mine tailings (mine district Freiberg, Germany) Applied Geochemistry 22:2486-2508 doi:http://dx.doi.org/10.1016/j.apgeochem.2007.07.002

Guevara-Riba A, Sahuquillo A, Rubio R, Rauret G (2004) Assessment of metal mobility in dredged harbour sediments from Barcelona, Spain Science of The Total Environment 321:241-255 doi:http://dx.doi.org/10.1016/j.scitotenv.2003.08.021

Huerta-Diaz MA, Tessier A, Carignan R (1998) Geochemistry of trace metals associated with reduced sulfur in freshwater sediments Applied Geochemistry 13:213-233 doi:10.1016/s0883-2927(97)00060-7

Isaure M-P et al. (2002) Quantitative Zn speciation in a contaminated dredged sediment by $\mu$-PIXE, $\mu-S X R F$, EXAFS spectroscopy and principal component analysis Geochimica et Cosmochimica Acta 66:15491567 doi:10.1016/s0016-7037(01)00875-4

Isaure M-P, Manceau A, Geoffroy N, Laboudigue A, Tamura N, Marcus MA (2005) Zinc mobility and speciation in soil covered by contaminated dredged sediment using micrometer-scale and bulkaveraging X-ray fluorescence, absorption and diffraction techniques Geochimica et Cosmochimica Acta 69:1173-1198 doi:10.1016/j.gca.2004.08.024

Jones B, Turki A (1997) Distribution and speciation of heavy metals in surficial sediments from the Tees Estuary, north-east England Marine Pollution Bulletin 34:768-779 doi:10.1016/s0025-326x(97)00047-7

Le Guyader C (2011) Enquête "Dragage 2009" - Synthèse des données. CETMEF, Margny Lès Compiègne (in French)

Le Guyader C (2013) Enquête "Dragage 2010" - Synthèse des données. CETMEF, Margny Lès Compiègne (in French)

Lions J, Guérin V, Bataillard P, van der Lee J, Laboudigue A (2010) Metal availability in a highly contaminated, dredged-sediment disposal site: Field measurements and geochemical modeling Environmental Pollution 158:2857-2864 doi:10.1016/j.envpol.2010.06.011

Lions J, van der Lee J, Guérin V, Bataillard P, Laboudigue A (2007) Zinc and cadmium mobility in a 5-year-old dredged sediment deposit: Experiments and modelling Journal of Soils and Sediments 7:207-215 doi:10.1065/jss2007.05.226

Lowers HA, Breit GN, Foster AL, Whitney J, Yount J, Uddin MN, Muneem AA (2007) Arsenic incorporation into authigenic pyrite, Bengal Basin sediment, Bangladesh Geochimica et Cosmochimica Acta 71:26992717 doi:http://dx.doi.org/10.1016/j.gca.2007.03.022

Lowson RT (1982) Aqueous oxidation of pyrite by molecular oxygen Chemical Reviews 82:461-497 doi:10.1021/cr00051a001

Mamindy-Pajany Y, Geret F, Roméo M, Hurel C, Marmier N (2012) Ex situ remediation of contaminated sediments using mineral additives: Assessment of pollutant bioavailability with the Microtox solid phase test Chemosphere 86:1112-1116 doi:http://dx.doi.org/10.1016/j.chemosphere.2011.12.001

Mbonimpa M, Akué Awoh S, Aubertin M (2012) A simple interpretation for the modified oxygen consumption test on sulphide tailings. Paper presented at the GeoManitoba, Winnipeg, Canada,

Mbonimpa M, Aubertin M, Aachib M, Bussière B (2003) Diffusion and consumption of oxygen in unsaturated cover materials Canadian Geotechnical Journal 40:916-932 doi:doi:10.1139/t03-040

Morse JW, Luther Iii GW (1999) Chemical influences on trace metal-sulfide interactions in anoxic sediments Geochimica et Cosmochimica Acta 63:3373-3378 doi:10.1016/s0016-7037(99)00258-6

Mtambanengwe F, Mapfumo P, Kirchmann H (2004) Decomposition of organic matter in soil as influenced by texture and pore size distribution Managing nutrient cycles to sustain soil fertility in sub-Saharan Africa Ed, Bationo, A Centro Internacional de Agriculture Tropical pp:261-276

Ouangrawa M, Molson J, Aubertin M, Bussière B, Zagury GJ (2009) Reactive transport modelling of mine tailings columns with capillarity-induced high water saturation for preventing sulfide oxidation Applied Geochemistry 24:1312-1323 doi:http://dx.doi.org/10.1016/j.apgeochem.2009.04.005

Ouellet S, Bussière B, Mbonimpa M, Benzaazoua M, Aubertin M (2006) Reactivity and mineralogical evolution of an underground mine sulphidic cemented paste backfill Minerals Engineering 19:407-419 doi:10.1016/j.mineng.2005.10.006

Pierret M-C, Blanc G, Clauer N (2000) Sur l'origine de la pyrite framboïdale dans les sédiments de la fosse Suakin (mer Rouge) Comptes Rendus de l'Académie des Sciences - Series IIA - Earth and Planetary Science 330:31-38 doi:10.1016/s1251-8050(00)00103-8

Pourbaix M, de Zoubov N, Van Muylder J (1963) Atlas d'équilibres électrochimiques vol 1. Gauthier-Villars Paris, 
Prokop Z, Vangheluwe ML, Van Sprang PA, Janssen CR, Holoubek I (2003) Mobility and toxicity of metals in sandy sediments deposited on land Ecotoxicology and Environmental Safety 54:65-73 doi:10.1016/s0147-6513(02)00022-2

Puget P, Chenu C, Balesdent J (2000) Dynamics of soil organic matter associated with particle-size fractions of water-stable aggregates European Journal of Soil Science 51:595-605 doi:10.1111/j.13652389.2000.00353.x

Raudsepp M, Pani E (2003) Application of Rietveld analysis to environmental mineralogy Environmental aspects of mine wastes Mineralogical Association of Canada Short Course 3:165-180

Ribecco C, Baker ME, Śášik R, Zuo Y, Hardiman G, Carnevali O (2011) Biological effects of marine contaminated sediments on Sparus aurata juveniles Aquatic Toxicology 104:308-316 doi:http://dx.doi.org/10.1016/j.aquatox.2011.05.005

Salomons W, Rooij NM, Kerdijk H, Bril J (1987) Sediments as a source for contaminants? Hydrobiologia 149:13-30 doi:10.1007/bf00048643

Sauvé S, Hendershot W, Allen HE (2000) Solid-Solution Partitioning of Metals in Contaminated Soils: Dependence on pH, Total Metal Burden, and Organic Matter Environmental Science \& Technology 34:1125-1131 doi:10.1021/es9907764

Schenau SJ, Passier HF, Reichart GJ, de Lange GJ (2002) Sedimentary pyrite formation in the Arabian Sea Marine Geology 185:393-402 doi:http://dx.doi.org/10.1016/S0025-3227(02)00183-4

Schippers A, Jørgensen BB (2002) Biogeochemistry of pyrite and iron sulfide oxidation in marine sediments Geochimica et Cosmochimica Acta 66:85-92 doi:10.1016/s0016-7037(01)00745-1

Sobek AA, Schuller WA, Freeman JR, Smith RM (1978) Field and laboratory methods applicable to overburden and minesoils vol Report EPA-600/2-78-054. US Environmental Protection Agency, (in

Staniszewska M, Burska D, Sapota G, Bogdaniuk M, Borowiec K, Nosarzewska I, Bolałek J (2011) The relationship between the concentrations and distribution of organic pollutants and black carbon content in benthic sediments in the Gulf of Gdańsk, Baltic Sea Marine Pollution Bulletin 62:1464-1475 doi:http://dx.doi.org/10.1016/j.marpolbul.2011.04.013

Sundaray SK, Nayak BB, Lin S, Bhatta D (2011) Geochemical speciation and risk assessment of heavy metals in the river estuarine sediments-A case study: Mahanadi basin, India Journal of Hazardous Materials 186:1837-1846 doi:http://dx.doi.org/10.1016/j.jhazmat.2010.12.081

Tanji KK (1969) Solubility of gypsum in aqueous electrolytes as affected by ion association and ionic strengths up to $0.15 \mathrm{M}$ and at 25.deg Environmental Science \& Technology 3:656-661 doi:10.1021/es60030a003

Tessier E, Garnier C, Mullot J-U, Lenoble V, Arnaud M, Raynaud M, Mounier S (2011) Study of the spatial and historical distribution of sediment inorganic contamination in the Toulon bay (France) Marine Pollution Bulletin 62:2075-2086 doi:http://dx.doi.org/10.1016/j.marpolbul.2011.07.022

Trefry JH, Metz S (1984) Selective leaching of trace metals from sediments as a function of $\mathrm{pH}$ Analytical Chemistry 56:745-749 doi:10.1021/ac00268a034

Visconti F, De Paz JM, Rubio JL (2010) Calcite and gypsum solubility products in water-saturated salt-affected soil samples at $25^{\circ} \mathrm{C}$ and at least up to $14 \mathrm{dS} \mathrm{m}-1$ European Journal of Soil Science 61:255-270 doi:10.1111/j.1365-2389.2009.01214.x

Warwick P, Hall A, Pashley V, Van der Lee J, Maes A (1998) Zinc and cadmium mobility in sand: effects of $\mathrm{pH}$, speciation, Cation Exchange Capacity (CEC), humic acid and metal ions Chemosphere 36:22832290 doi:http://dx.doi.org/10.1016/S0045-6535(97)10197-7

Ye S, Laws EA, Zhong S, Ding X, Pang S (2011) Sequestration of metals through association with pyrite in subtidal sediments of the Nanpaishui Estuary on the Western Bank of the Bohai Sea, China Marine Pollution Bulletin 62:934-941 doi:http://dx.doi.org/10.1016/j.marpolbul.2011.02.052

Young RA (1993) The Rietveld method. Oxford University Press, NYC, NY, USA 


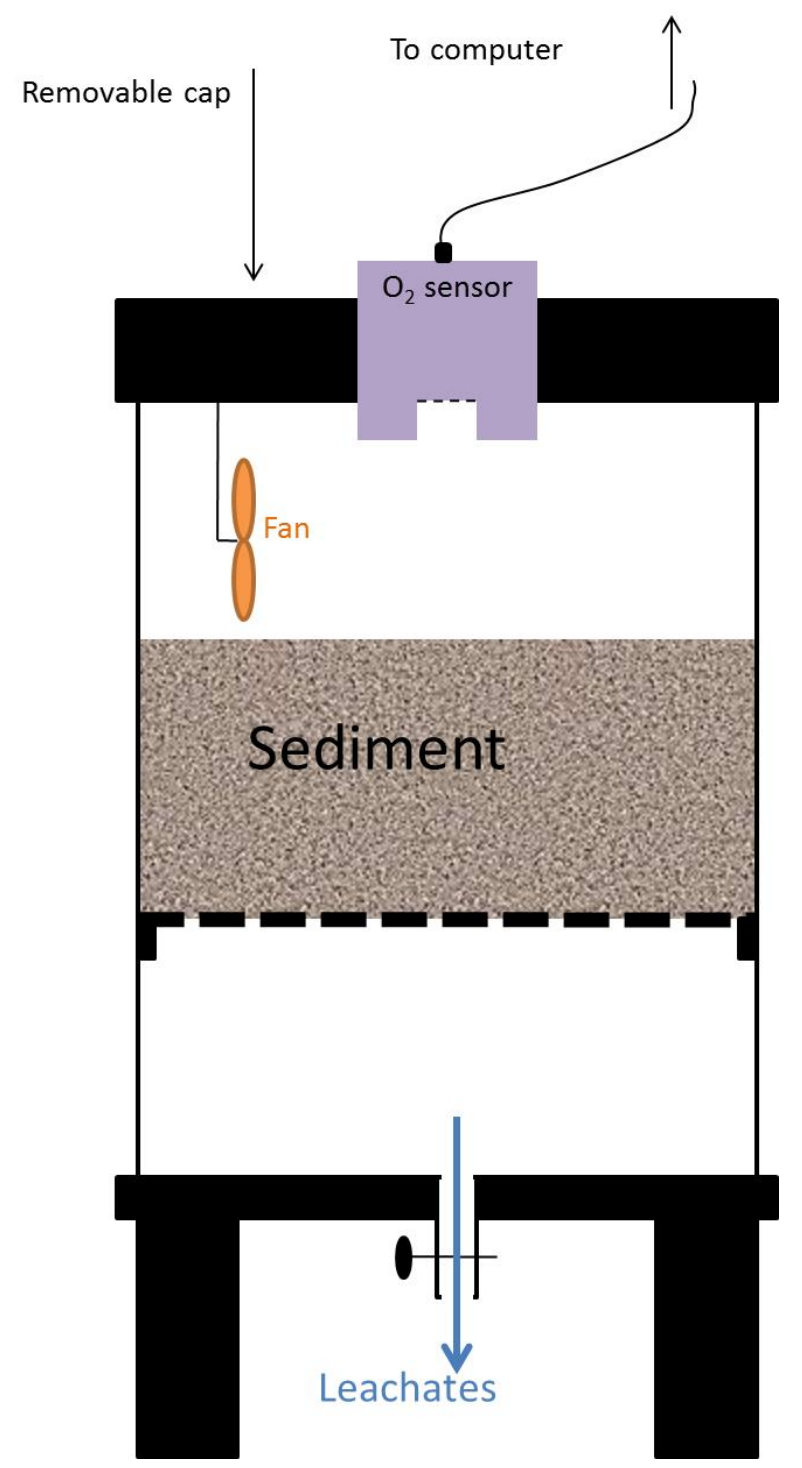

Fig. 1 Schematic illustration of the experimental set-up for leaching and OC tests 


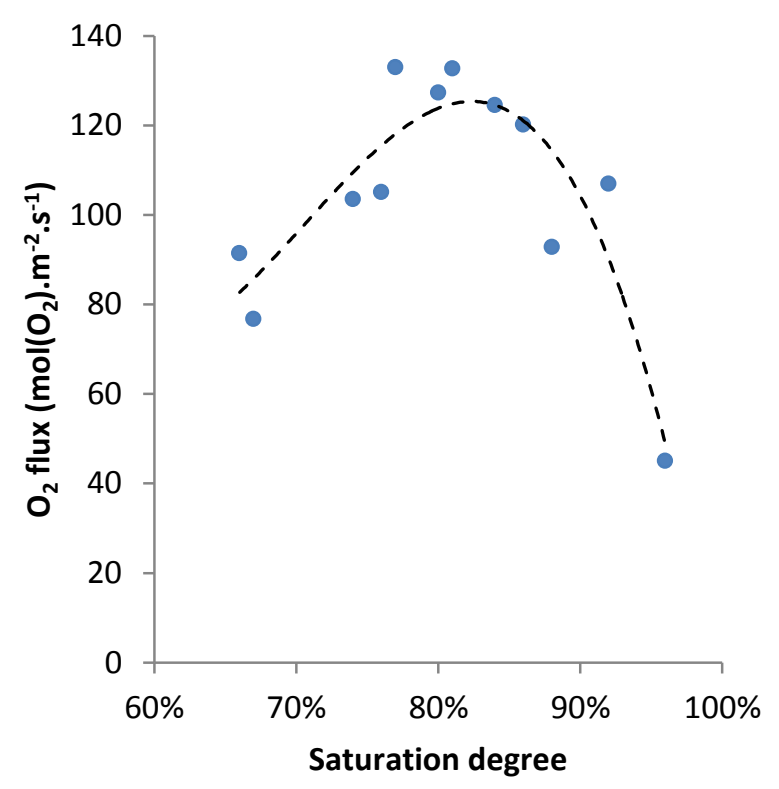

Fig. 2 Dependence of OC to saturation degree with calculated oxygen flux from OC-Test in $\operatorname{mol}\left(\mathrm{O}_{2}\right) \cdot \mathrm{m}^{-2} \cdot \mathrm{s}^{-1}$ 


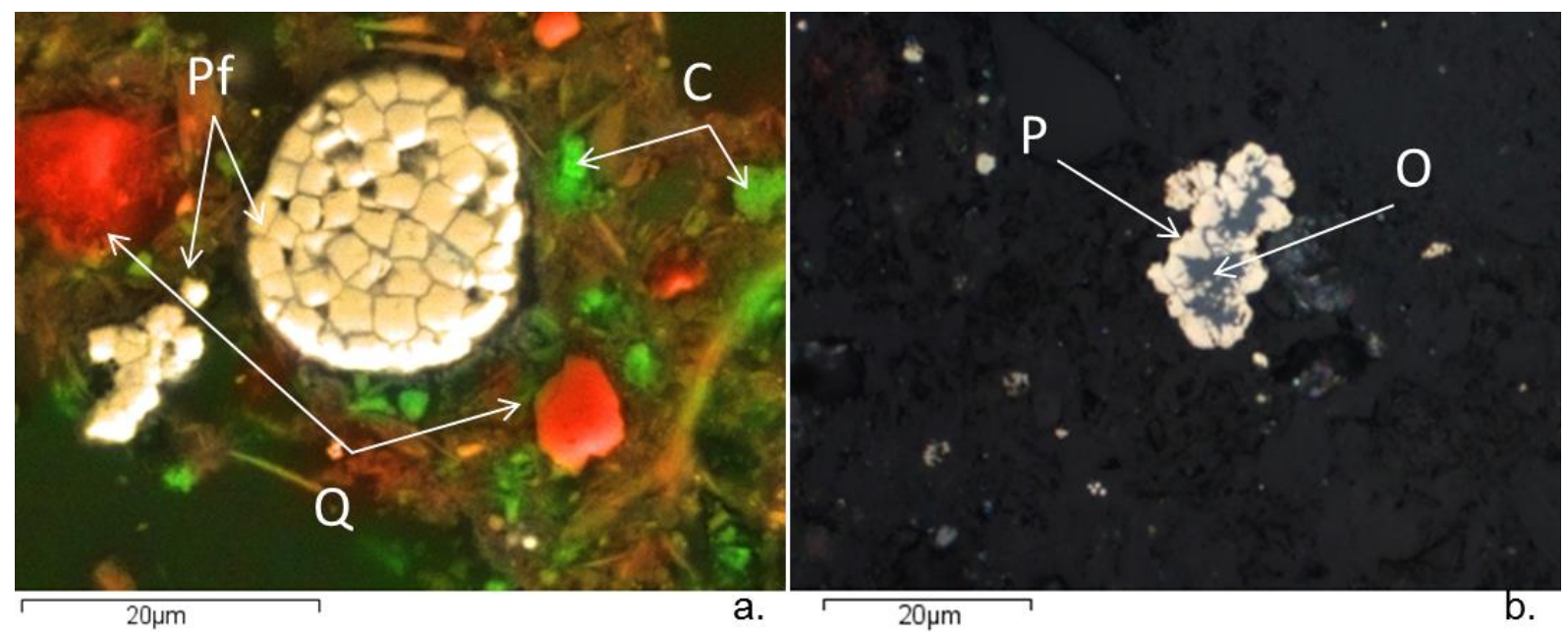

Fig. 3 SEM-EDS back-scattered electron images of sediment showing framboïdal pyrite (Pf, a) surrounded by a complex aggregate containing quartz $(\mathrm{Q}$, red color) and calcite $(\mathrm{C}$, green color), and massive pyrite $(\mathrm{P}, \mathrm{b})$ with an Fe-oxi-hydroxides replacement $(\mathrm{O})$ 

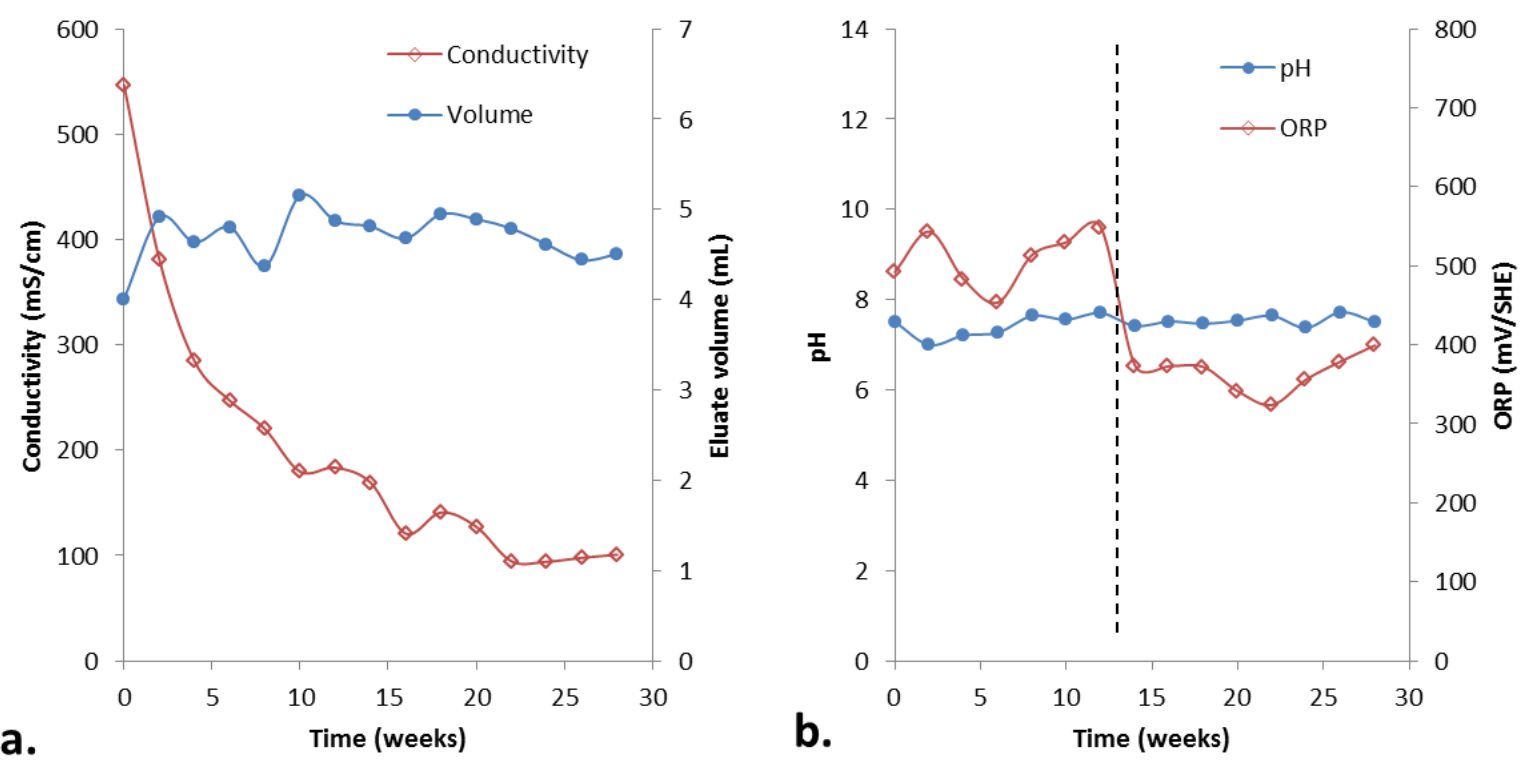

Fig. 4 Evolution of leachates volume, conductivity (a), pH, and ORP (b) during the column leaching test; vertical dashed line in (b) indicates a change in geochemical behavior after $12^{\text {th }}$ week 

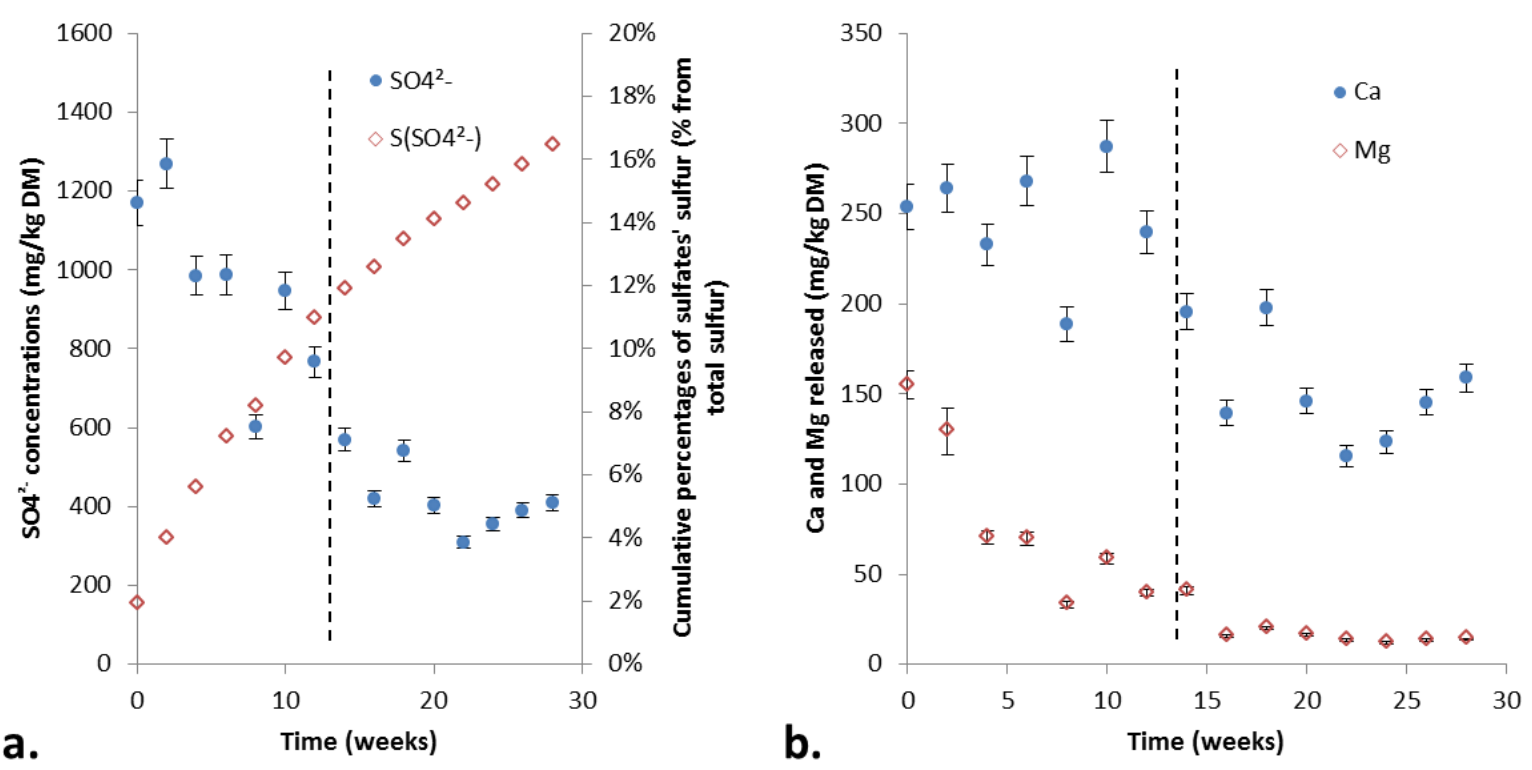

Fig. 5 Sulfates concentrations ( $\mathrm{mg} / \mathrm{kg}$ of dry matter $(\mathrm{DM})$ ), cumulative percentages of sulfates fraction of sulfur (in \% from total sulfur) (a), $\mathrm{Ca}$, and $\mathrm{Mg}$ concentrations (in $\mathrm{mg} / \mathrm{kg}$ $\mathrm{DM}, \mathrm{b}$ ) in leaching solutions during the column leaching test; vertical dashed line indicates a change in geochemical behavior after $12^{\text {th }}$ week 


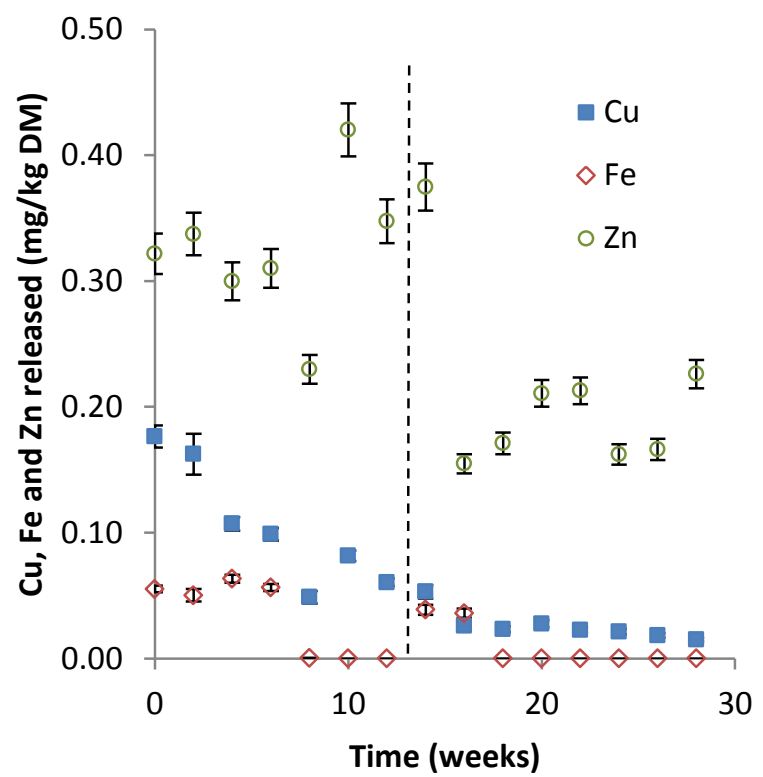

Fig. $6 \mathrm{Cu}, \mathrm{Fe}$ and $\mathrm{Zn}$ concentrations into leachates during the column leaching test; vertical dashed line indicates a change in geochemical behavior after $12^{\text {th }}$ week 


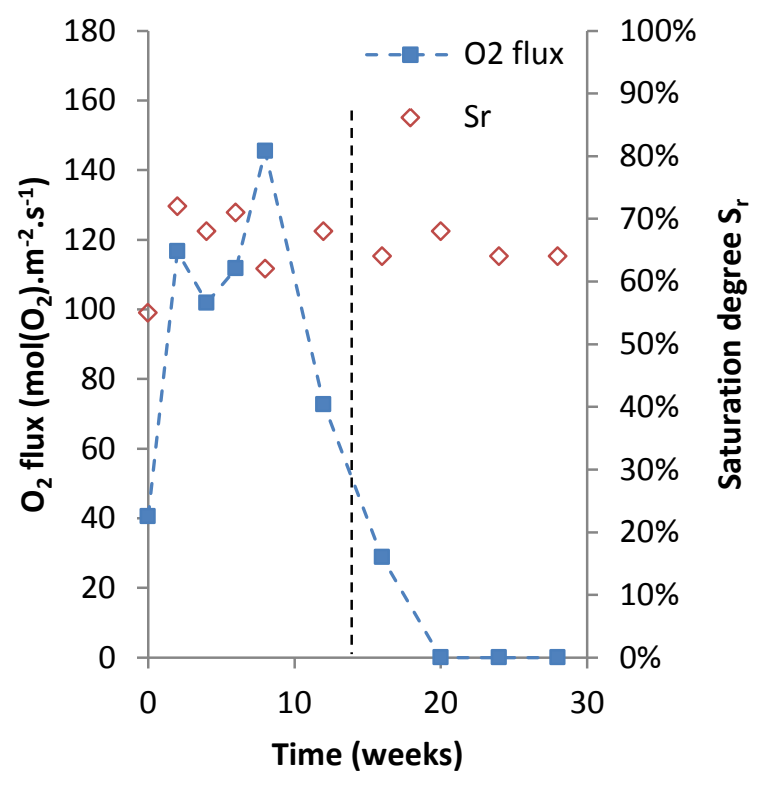

Fig. 7 Oxygen consumption into OC-Test with oxygen flux and corresponding saturation degree $S_{r}$; vertical dashed line indicates a change in geochemical behavior after $12^{\text {th }}$ week 


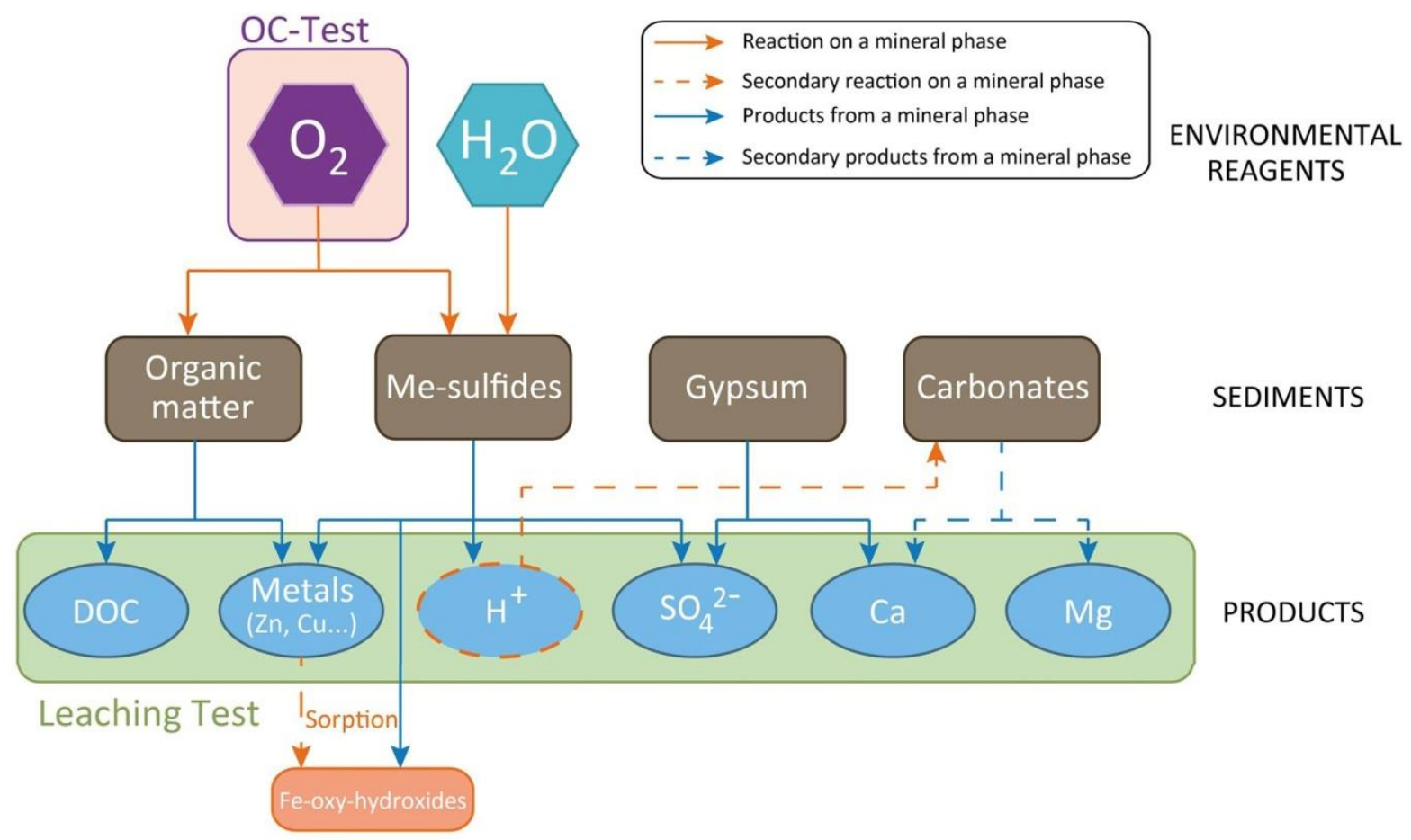

Fig. 8 Reactional schema of involved components into marine sediments and methodological protocol analysis 

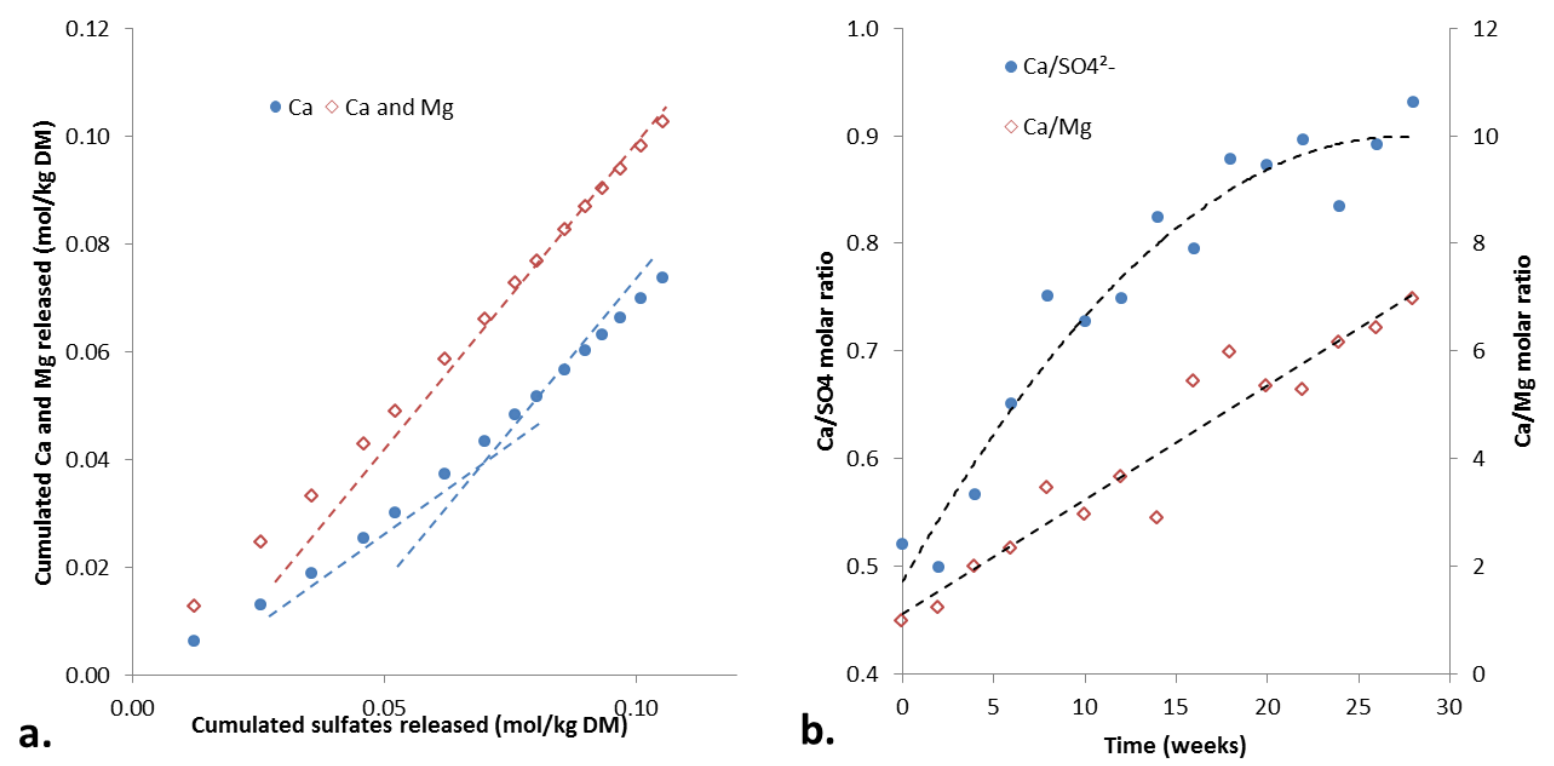

Fig. 9 Cumulated $\mathrm{Ca}$ and $\mathrm{Ca}+\mathrm{Mg}$ released molar concentrations versus cumulated sulfates released molar concentrations (a), evolution of $\mathrm{Ca}$ versus sulfates molar ratio, and $\mathrm{Ca}$ versus $\mathrm{Mg}$ molar ratio versus time (b) into leachates 


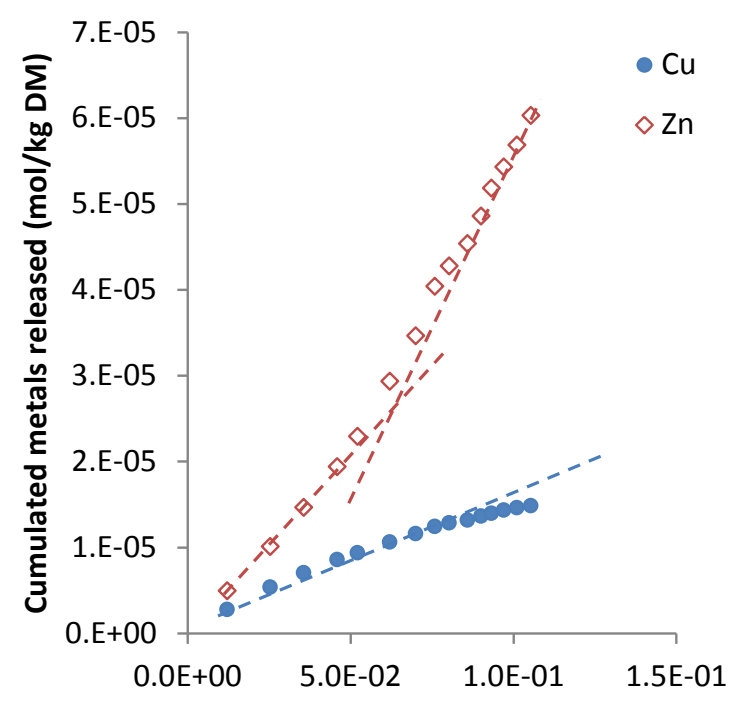

a.

Cumulated sulfates released ( $\mathrm{mol} / \mathrm{kg} \mathrm{DM}$ )

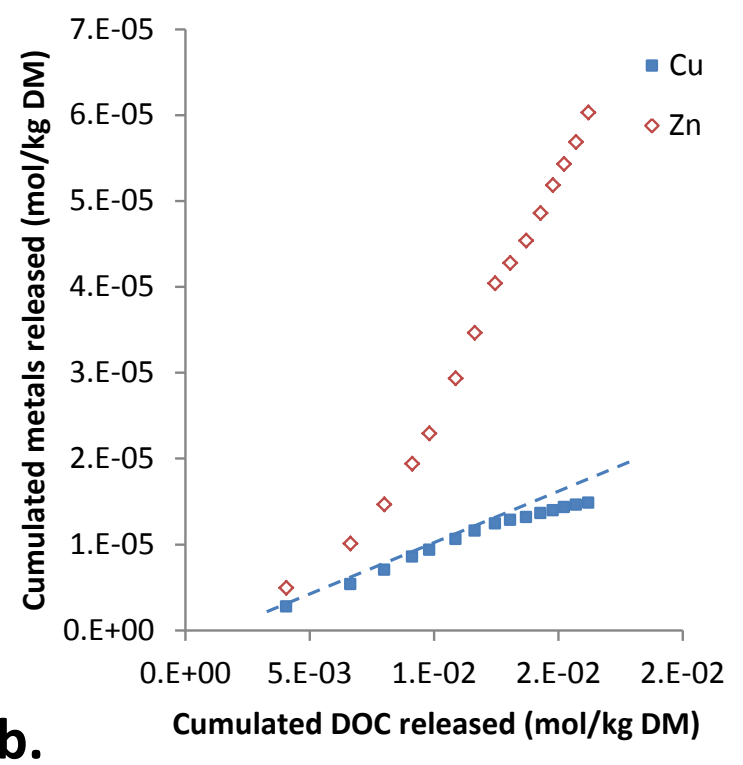

b.

Fig. 10 Correlation between cumulated $\mathrm{Cu}$ and $\mathrm{Zn}$ molar concentrations and cumulated sulfates molar concentrations (a), and cumulated DOC (b) in the leachates 
Table 1 Physicochemical characteristics of the sediment

\begin{tabular}{cccccccc}
\hline Gs $\left(\mathrm{g} / \mathrm{cm}^{3}\right)$ & $\begin{array}{c}\text { Water } \\
\text { content } \\
(\text { wt.\%) }\end{array}$ & $\begin{array}{c}\text { Total } \\
\text { carbon } \\
(\text { wt.\%) }\end{array}$ & $\begin{array}{c}\text { TOC } \\
(\text { wt.\%) }\end{array}$ & $\begin{array}{c}\text { Total } \\
\text { sulfur } \\
(\text { wt.\%) }\end{array}$ & $\begin{array}{c}\mathrm{HCl} \text { extractable } \\
\text { sulfur } \\
(w t . \%)\end{array}$ & $\begin{array}{c}\text { Other } \\
\text { sulfur } \\
\text { forms } \\
\text { (wt.\%) }\end{array}$ \\
\hline $\begin{array}{c}\text { Bulk } \\
\text { Sediment }\end{array}$ & 2.55 & 23.3 & 9.89 & 6.27 & 2.02 & 1.04 & 0.98 \\
\hline
\end{tabular}


Table 2 Chemical composition of the sediment (ICP-AES) and comparison to the regulatory threshold levels N1 and N2 for trace metals (French regulation)

\begin{tabular}{cccccccc}
\hline & $\mathrm{Ca}($ wt.\%) & $\begin{array}{c}\mathrm{Mg} \\
(\text { wt.\% })\end{array}$ & $\begin{array}{c}\mathrm{Na} \\
(\text { wt.\% })\end{array}$ & $\mathrm{Fe}($ wt.\%) & $\begin{array}{c}\mathrm{Cu} \\
(\mathrm{mg} / \mathrm{kg})\end{array}$ & $\begin{array}{c}\mathrm{Pb} \\
(\mathrm{mg} / \mathrm{kg})\end{array}$ & $\begin{array}{c}\mathrm{Zn} \\
(\mathrm{mg} / \mathrm{kg})\end{array}$ \\
\hline Bulk & 19.7 & 2.07 & 0.3 & 3.38 & 930 & 1020 & 2250 \\
Sediment & & - & - & - & 45 & 100 & 276 \\
N1 level & - & - & - & - & 90 & 200 & 552 \\
N2 level & - & - & & &
\end{tabular}


Table 3 XRD mineralogical analysis of the sediment with concentrations calculated accordingly to Rietveld method (Young 1993)

\begin{tabular}{llc}
\hline Name & Formulas & Concentration \\
\hline Quartz & $\mathrm{SiO}_{2}$ & 15.3 \\
Muscovite & $\mathrm{KAl}_{2}\left(\mathrm{Si}_{3} \mathrm{Al}\right) \mathrm{O}_{10}(\mathrm{OH}, \mathrm{F})_{2}$ & 9.2 \\
Chamosite & $(\mathrm{Fe}, \mathrm{Mg})_{5} \mathrm{Al}\left(\mathrm{Si}_{3} \mathrm{Al}\right) \mathrm{O}_{10}(\mathrm{OH}, \mathrm{O})$ & 4.5 \\
Illite & $\left(\mathrm{K}, \mathrm{H}_{3} \mathrm{O}\right)(\mathrm{Al}, \mathrm{Mg}, \mathrm{Fe})_{2}(\mathrm{Si}, \mathrm{Al})_{4} \mathrm{O}_{10}\left[(\mathrm{OH})_{2},\left(\mathrm{H}_{2} \mathrm{O}\right)\right]$ & 1.6 \\
Kaolinite & $\mathrm{Al}_{2} \mathrm{Si}_{2} \mathrm{O}_{5}(\mathrm{OH})_{4}$ & 4.0 \\
Dolomite & $\left.\mathrm{CaMg}_{(\mathrm{CO}}\right)_{2}$ & 13.6 \\
Calcite & $\mathrm{CaCO}_{3}$ & 38.9 \\
Halite & $\mathrm{NaCl}_{\text {Pyrite }} \mathrm{FeS}_{2}$ & 0.8 \\
Magnétite & $\mathrm{Fe}_{3} \mathrm{O}_{4}$ & 2.0 \\
Gypse & $\mathrm{CaSO}_{4} ; 2 \mathrm{H}_{2} \mathrm{O}$ & 1.1 \\
\hline
\end{tabular}

